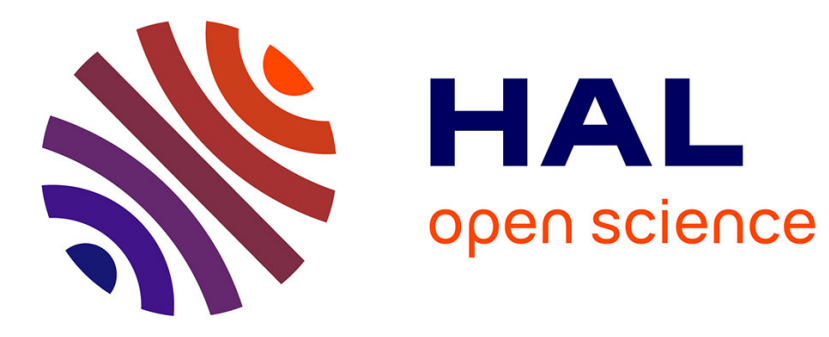

\title{
Mapping a Value Stream with the Perspective of Sustainability
}

Veronica Lindström, Niklas Ingesson

\section{To cite this version:}

Veronica Lindström, Niklas Ingesson. Mapping a Value Stream with the Perspective of Sustainability. IFIP International Conference on Advances in Production Management Systems (APMS), Sep 2016, Iguassu Falls, Brazil. pp.892-899, 10.1007/978-3-319-51133-7_105 . hal-01615789

\section{HAL Id: hal-01615789 \\ https://hal.inria.fr/hal-01615789}

Submitted on 12 Oct 2017

HAL is a multi-disciplinary open access archive for the deposit and dissemination of scientific research documents, whether they are published or not. The documents may come from teaching and research institutions in France or abroad, or from public or private research centers.
L'archive ouverte pluridisciplinaire HAL, est destinée au dépôt et à la diffusion de documents scientifiques de niveau recherche, publiés ou non, émanant des établissements d'enseignement et de recherche français ou étrangers, des laboratoires publics ou privés.

\section{(c)(1)}

Distributed under a Creative Commons Attribution| 4.0 International License 


\title{
Mapping a Value Stream with the Perspective of Sustainability
}

\author{
Veronica Lindström $^{1}$ and Niklas Ingesson ${ }^{2}$ \\ 1 Linköping University, Sweden \\ Veronica.lindstrom@liu.se \\ 2 TitanX Engine Cooling AB, Linköping, Sweden \\ Niklas.Ingesson@titanx.com
}

\begin{abstract}
Companies align lean production and sustainability differently depending on organization model. Lean provides social foundation for sustainability and makes it possible to implement sustainability, and integrate lean and sustainability. The work presented here maps a current value stream with measures from different methodologies presented in the literature. The objective of this paper is to integrate sustainability measures with a traditional value stream mapping. Economic, environmental, and societal metrics are presented. The result indicates that the interest of the different metrics depends on the role within the organization..
\end{abstract}

Keywords: Lean production - Manufacturing - Production operations - Value stream mapping.

\section{Introduction}

Industrial companies that compete on a global market can choose to differentiate their manufacturing strategy depending on product family and its niche consumer. If industrial companies choose to differentiate their products towards a more narrow competitive scope and thus apply a differentiation strategy [1], sustainability as a competitive priority may be an order winner for a niche market [2] and may improve international competitiveness [3]. The competitive priority sustainability is thus adding a higher value to those niche markets and its customers. However, industrial companies within the car and truck industry compete today with products that are mature and thus need to find ways to add value besides continuous total cost reductions. Companies within the car and truck industry have applied Lean production for some decades with the purpose to eliminate waste in their value streams to add value. One common used tool is Value Stream Mapping (VSM). VSM is a tool to find and eliminate waste in a value stream. The original value stream is defined as the value stream for the end customer, or consumer. Lean thinking provides a way to specify value [4]. The basis for lean production development is to eliminate waste. According to the theory of lean thinking, one can learn to see the waste by mapping a value stream [5]. Recent research on the application of value stream mapping 
adds sustainability measures and integrates thus additional measures to evaluate environmental impact and societal well-being $[6,7]$.

The work presented in this paper focuses on the integration of sustainability measures in a traditional VSM. Environmental measurements have been applied similar to the work of Sus-VSM $[6,7]$. The ergonomic measurements have been applied according to the study presented as the method ErgoVSM [8].

\section{Frame of Reference}

\subsection{Sustainability in Production Operations}

Sustainability at the company level concerns the development of products, processes, and business models [2]. Therefore, product and process innovations will be needed to achieve sustainable production [9]. It also requires a holistic view and improved product performance models and optimization of individual manufacturing processes, to give some examples [9]. Several articles in the literature describe sustainable production. Issues within this area include managing processes with an input such as energy, people, equipment and machines with the objective of reducing waste, carbon footprint, rework, inventory and delays [10]. Sustainable production operations should lead to improvements in competitive priorities such as flexibility, customization, responsiveness, dependability, cost reduction and high quality of products and services [10]. To promote sustainability-driven decision-making, a socalled value creating framework could be applied in organizations where five factors are considered; product, process, equipment, organization, and human [11].

Companies applying lean manufacturing and its concepts align sustainability differently in their respective organizations depending on organizational model in the company [12]. Companies with a traditional organizational model tend to lack executive involvement and worker commitment that leads to that sustainability is underdevel-oped. On the other extreme, companies with advanced organizational model tend to involve workers, and those companies have also a high cross-functional executive involvement [12]. To achieve sustainability in production operations, managers are suggested to apply methods and programs like just-in-time production, lean, total quality management, Kanban etc. [10]. According to Piercy and Rich [13], lean provides social foundation for sustainability and pairs it with technical system, which makes it possible to implement sustainability and thus integrate lean and sustainability [13].

\subsection{Sustainability and Value Streams}

Lean production principles start with defining "value" [4]. A value stream is the "set of all the specific actions required to bring a specific product through the three critical management tasks of any business: the problem-solving task running from concept through detailed design and engineering to production launch, the information management task running from order-taking through 
detailed scheduling to delivery, and the physical transformation task proceeding from raw materials to a finished product in the hands of the customer." (Womack and Jones, page 19) [4].

Sustainability is defined as taking into consideration the triple bottom line, i.e. economic, environmental, and societal goals $[2,14]$.

\subsection{Different Types and Metrics of Sustainable Value Stream Mappings}

Applying Lean production means to get the knowledge, leadership and it starts to identify the value streams [4]. Once you have identified a value stream, one can start to map it. Value Stream Mapping, VSM, is a lean tool that aims to reduce waste [4]. VSM can be a communication tool or a business planning tool, and a tool for managing the change processes of the company [5]. The mapping begins at "a door-to-door level" and includes the mapping of material- and information flows of operations. The measurements of the original VSM are mainly time and inventory (quantity) [5].

Sustainable value stream mapping (Sus-VSM) is a VSM that, in addition to lead time, includes environmental and societal metrics $[6,7]$. The metrics types are thus economic, environmental, and societal metrics [7]. The environmental metrics consist of energy consumption, raw material usage, and process water usage. The societal metrics consist of the metrics of physical load and work environment metrics such as noise, risks for electrical systems, hazardous chemical/materials used, pressurized systems, and high-speed components [6].

Product Sustainability Index (ProdSI) is an assessment of the overall product sustainability throughout its product life cycle [15]. ProdSI is the overall aggregated product sustainability performance index, which consists of three subindex; economic, environmental, and societal. The ProdSI methodology suggests that individual metrics should be used and customized for each specific case [15].

ErgoVSM is a lean tool for integration of ergonomics in manufacturing in a value stream mapping activity [8]. ErgoVSM considers physical exposure. It assesses physical exposure and is structured by tasks, value streams, and job level. Similar to Sus-VSM, ErgoVSM is embedded in the original VSM tool by Rother and Shook [5].

\section{Methodology}

The methodology used in this study is the case methodology. For the application of sustainability metrics in a value stream, a single case is used. The reason for choosing a single case was for the purpose of a pilot study [16]. The choice of the specific case was chosen for its location, accessibility, and its application of JIT and lean principles, which, according to theory, has relationship to sustainability $[12,13]$. The advantage of a single case is that it can provide greater depth, and the limits of a single case is whether one can make any generalizations or 
conclusions [17]. The study presented here was conducted from January through March 2016, and has included observations, interviews, and empirical data collection. To increase reliability and validity of this case, the principle informant in the case company was active during the whole process of setting up the research, data collection, and analyzing data. The approach presented here follows a typical deductive research, i.e. applying or revising an existing framework or hypothesis [18]. Following suggested approach for deductive case studies, the unit of analysis should be articulated and the case justified [18].

\subsection{The Case Company and the Product of the Value Stream}

TitanX is a dedicated supplier of engine and oil cooling products to the Commercial Vehicle industry. The company TitanX Engine Cooling AB in Linköping, Sweden, had a turnover of 329 Million SEK in year 2015. Their main customers are Volvo Trucks and Scania. The factory has been situated in Linköping since 1895. Since year 2008 the factory is owned by TitanX, which is a global manufacturer of powertrain cooling solutions to the commercial vehicle industry. The factory in Linköping, as well as the other manufacturing sites at TitanX, applies lean manufacturing principles. TitanX has their own production system called "TIPS" (TitanX Production System). The factory in Linköping strives towards operational excellence and World Class capabilities.

The product chosen for the application of the value stream mapping is a SFI cooler, see Figure 1. The production system of the SFI cooler has developed from a batch flow to a JIT production system, using Kanban and sequencing pull. The reason for choosing this product for mapping purposes is that this

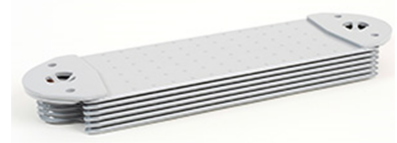

Fig. 1. Example of an SFI cooler

cooler represents a modern manufacturing process and is thus interesting to map depending on possibility of future improvements. The product chosen consists of 9 turbulators of carbon steel, 18 plates of stainless steel plus on top plate, 8 foils of copper, two connections of stainless steel, and some rivets.

\subsection{Data Collection}

The data collection of this case study followed three different methodologies for the respective sustainability factor, see 3.2.1 to 3.2.3 below. 


\subsection{Economic Measures}

The data collection of economic measures follows the VSM methodology by Rother and Shook [5]. First, a product family was chosen. A team of three people were mapping the value stream from "door-to-door" in the factory. Both material and information flows were mapped. Working times, cycle times, setup times, OEE, scrap rates, and inventory levels were collected by either clocking the times or capturing the data from machine data that is stored. Inventory levels were counted manually on the shop-floor. The lead time from door-to-door was calculated, as well as the value-added time.

\subsection{Environmental Measures}

The data collection of environmental measures follows the Sus-VSM methodology by Faulkner and Badurdeen [7]. Process water consumption was measured per product and is captured as used water consumption, i.e. required and net water consumption was not captured. It is only one process that uses water; the brazing operation, see Figure 2. Raw material was captured via data of raw material in the business system AS/400. After the stamping operation, the product was weighted. In this way, the lost material by the stamping process could be measured. Additional components in the pre-assembly station 2 and assembly station were weighted. Energy consumption was measured as direct energy consumption per manufacturing process by using the power rating per machine and using cycle time per product. This data was retrieved from the MPS-system. Transportation power rates were not captured in this study as well as indirect energy usage such as lightning, heating and so on.

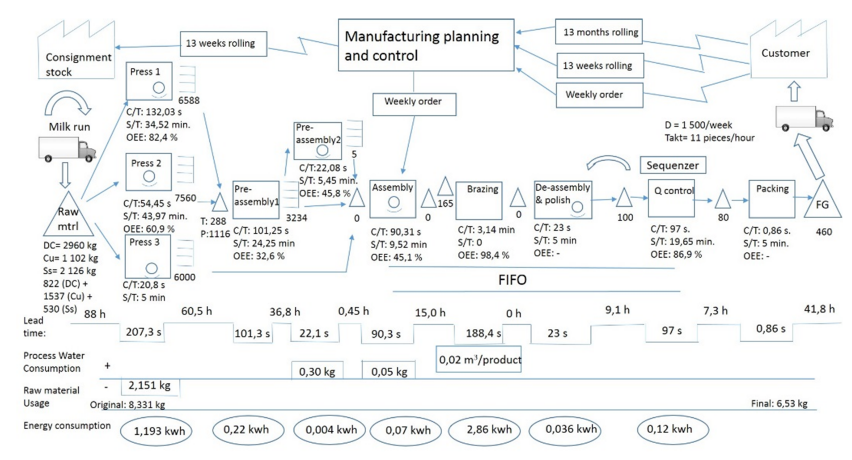

Fig. 2. Value Stream Map for the SFI cooler

\subsection{Societal Measures}

The data collection of societal measures follows the ErgoVSM methodology by Jarebrant et al. [8]. Ratings for five ergonomics issues are considered in this 
methodology; postures, forces, physical variation, and porosity on the value stream level. A fifth ergonomic issue is the physical variation in the job of the operators in the value stream [8]. By rating task category per work station, the potential of variation of the job is rated. If there is a wide range of task categories per workstation, the potential is higher than if the tasks are monotonous [8]. The lower the rating, the better potential. The impact on performance is measured via the working time and its potential of reducing it. On the other hand, ergonomic assessments have an impact on working environment and should be managed as an individual assessment of the production system.

\section{Result and Application of Sustainability of a Value Stream}

The current state map for the value stream with the perspective of sustainability is shown in Figure 2. As in a traditional VSM, information flow is shown in the upper part of the figure, the material flow is shown in the middle, and measurements in the bottom part of the figure. Key performance indicators for the value stream is shown in table 1 .

Table 1. Key performance indicators for value stream of the SFI cooler

\begin{tabular}{ll}
\hline \multicolumn{1}{c}{ KPI } & Value \\
\hline Total lead time & 1.75 weeks \\
Value-added time & $0.203 \mathrm{~h}$ \\
Percentage value-added time & $7.8 \%$ \\
Process water consumption & $0.02 \mathrm{~m} 3 /$ product \\
Raw material usage & $8.3 \mathrm{~kg} /$ product \\
Material utilization rate & $78 \%$ \\
Energy consumption & $4.5 \mathrm{kWh} /$ product \\
\hline
\end{tabular}

Results of the ergonomics assessment at the value stream level is shown in table 2 and results of the ergonomics assessment at the task level is shown in table 3 .

Table 2. Ergonomics assessment at the value stream level of the SFI cooler

\begin{tabular}{ll}
\hline Ergonomics potential & 5 \\
\hline Variation in jobs & 5 \\
\hline
\end{tabular}

The data collection of environmental and societal measures took longer time to understand and collect than the economic measures, which are known before by the company.

Especially the ergonomics assessment was hard to understand as no one in the data collection team had any expertise in ergonomics knowledge. 
Table 3. Ergonomics assessment at the task level in the value stream of the SFI cooler

\begin{tabular}{|c|c|c|c|c|}
\hline Task & $\begin{array}{l}\text { Manual } \\
\text { Working } \\
\text { Time (s) }\end{array}$ & $\begin{array}{c}\text { Posture } \\
\text { rating }\end{array}$ & $\begin{array}{l}\text { Force } \\
\text { rating }\end{array}$ & $\begin{array}{c}\text { Task } \\
\text { Category }\end{array}$ \\
\hline Press 1 & 8.9 & 3 & 4 & $\mathrm{C}$ \\
\hline$\overline{P r e s s} 2$ & 31.6 & 3 & 8 & $\mathrm{C}$ \\
\hline Press 3 & 1.2 & 3 & 4 & $\mathrm{C}$ \\
\hline $\begin{array}{l}\text { Pre-assembly } 1 \\
\end{array}$ & 32.4 & 3 & 3 & $\mathrm{E}$ \\
\hline Pre-assembly 2 & 22.1 & 3 & 3 & $\mathrm{E}$ \\
\hline Assembly & 90.3 & 5 & 3 & $\mathrm{E}$ \\
\hline Brazing & 3.9 & 2 & 2 & $\mathrm{C}$ and $\mathrm{A}$ \\
\hline De-assembly \& polish & 23 & 6 & 3 & $\mathrm{E}$ \\
\hline Q control & 5,5 & 3 & 3 & $\mathrm{E}$ \\
\hline Packing & 0,9 & 7 & 3 & $\mathrm{~A}$ and $\mathrm{C}$ \\
\hline
\end{tabular}

\section{Discussion}

The mapping of the value stream presented here is holistic in its approach and offers the possibility of process innovations regarding sustainability measures. Sustainability can be measured in a value stream by combining economic, environmental, and societal measures. Some of the measures are related to performance of the production system while ergonomic measures are related to work environment. From an operator point of view, the ergonomics measurements were seen as positive. Thus, operators have an interest in developing societal measures. From an executive point of view, the performance measures were easier to understand than societal measures. This may relate to the way executives are measured and how higher, more aggregated performance measures are set within the company. As the literature points out, the organizational model of a company impacts the way sustainability is developed internally. TitanX, the case company in this study, has already an organization that follows lean principles and thus both executive and worker involvement in place. The current state presented here is a pilot study where there is an improvement potential for involving workers and executives further for developing sustainability and integrate the measures on operational level. The result also indicates that there is a conflict of interests between economic, environmental, and societal measures.

\section{References}

1. Porter, M.E.: Competitive Advantage: Creating and Sustaining Superior Performance. New York: FreePress (1985)

2. Jovane, F., Yoshikawa, H., Alting, L., Boër, C., Westkamper, E., Williams, D., Tseng, M., Seliger, G., Paci, A.: The Incoming Global Technological and Industrial Revolution Towards Competitive Sustainable Manufacturing. CIRP AnnalsManufacturing Technology 57(2), 641-659 (2008) 
3. Epstein, M.J., Buhovac, A.R.: Making Sustainability Work: Best Practices in Managing and Measuring Corporate Social, Environmental, and Economic Impacts. Greenleaf Publishing Limited (2014)

4. Womack, J.P., Jones, D.T.: Lean Thinking: Banish Waste and Create Wealth in Your Corporation. Free Press, New York (2003)

5. Rother, M., Shook, J.: Learning to See: Value Stream Mapping to Add Value and Eliminate Muda. Lean Enterprise Institute, version 1.3 (2009)

6. Brown, A., Amundson, J., Badurdeen, F.: Sustainable Value Stream Mapping (SusVSM) in Different Manufacturing System Configurations: Application Case Studies. Journal of Cleaner Production 85, 164-179 (2014)

7. Faulkner, W., Badurdeen, F.: Sustainable Value Stream Mapping (Sus-VSM): Methodology to Visualize and Assess Manufacturing Sustainability Performance. Journal of Cleaner Production 85, 8-18 (2014)

8. Jarebrant, C., Winkel, J., Johansson Hanse, J., Mathiassen, S.E., Öjmertz, B.: ErgoVSM: A Tool for Integrating Value Stream Mapping and Ergonomics in Manufacturing. Human Factors and Ergonomics in Manufacturing \& Service Industries 26(2), 191-204 (2016)

9. Jayal, A., Badurdeen, F., Dillon, O., Jawahir, I.: Sustainable Manufacturing: Modeling and Optimization Challenges at the Product, Process and System Levels. CIRP Journal of Manufacturing Science and Technology 2(3), 144-152 (2010)

10. Gunasekaran, A., Spalanzani, A.: Sustainability of Manufacturing and Services: Investigations for Research and Applications. International Journal of Production Economics 140(1), 35-47 (2012)

11. Bilge, P., Badurdeen, F., Seliger, G., Jawahir, I.: Model-based Approach for Assessing Value Creation to Enhance Sustainability in Manufacturing. Procedia CIRP $17,106-111(2014)$

12. Longoni, A., Cagliano, R.: Cross-functional Executive Involvement and Worker Involvement in Lean Manufacturing and Sustainability Alignment. International Journal of Operations \& Production Management 35(9), 1332-1358 (2015)

13. Piercy, N., Rich, N.: The Relationship Between Lean Operations and Sustainable Operations. International Journal of Operations \& Production Management 35(2), 282-315 (2015)

14. Elkington, J.: Cannibals with Forks: The Triple Bottom Line of 21st Century Business (1999)

15. Shuaib, M., Seevers, D., Zhang, X., Badurdeen, F., Rouch, K.E., Jawahir, I.: Product Sustainability Index (ProdSI): A Metrics-based Framework to Evaluate the Total Life Cycle Sustainability of Manufactured Products. Journal of industrial ecology 18(4), 491-507 (2014)

16. Yin, R.K.: Case Study Research: Design and Methods. In: Sage Publications (2009)

17. Voss, C., Tsikriktsis, N., Frohlich, M.: Case Research in Operations Management. International journal of operations \& production management 22(2), 195-219 (2002)

18. Barratt, M., Choi, T.Y., Li, M.: Qualitative Case Studies in Operations Management: Trends, Research Outcomes, and Future Research Implications. Journal of Operations Management 29(4), 329-342 (2011) 